\title{
Shelving Books?: Representations of the Library in Contemporary Texts
}

In their introduction to a special edition of Comparative Critical Studies, Shane Weller and Ben Hutchinson observe that 'since the early 1990s it has become common practice in the humanities to refer to the "archival turn"'. This now twentyyear-old critical phenomenon, bolstered by Derrida's almost compulsorily cited Mal d'Archive (1995) and, retroactively, by Foucault's archival theorisations, ${ }^{2}$ has developed to such an extent that, as Weller and Hutchison reflect, an archive of archive studies could now be constituted. ${ }^{3}$ But what of the archive's apparently less glamorous relation: the library? Marlene Manoff points out that the latter has all too often been conflated with the archive in the context of archival studies. ${ }^{4}$ Since the turn of the century, however, notably in a period marked by accelerated digitisation, a growing number of critical studies and histories attest to a renewed interest in the library as a distinct object of inquiry. At the same time, a body of fiction cutting across a range of nationalities and genres offers a particular vision of the library, representing it both in its relation to digital technology and as an affective, nostalgic construct. The 'turn' to the archive was very much a consequence of its dematerialisation and (re)conceptualisation: perhaps a similar process might be visited upon the library, generating if not Derridean 'library fever', then at least a mild raising of the temperature. What follows lays down some tracks, I hope, for just such a process.

A number of studies of the library began to appear a few years into the new century, foremost amongst them Matthew Battles' Library. An Unquiet History (2003), a loosely chronological approach articulated around 'points of transformation' at which 
the meaning of the library has been called into question, and Alberto Manguel's The Library at Night (2006), a succession of thematically organised meditations on the significance of libraries, taking the author's personal collection as a starting point. $^{5}$ More conventional recent histories include Konstantinos Staikos' multi-volume The History of the Library in Western Civilisation (2004-13), ${ }^{6}$ Fred Lerner's The Story of Libraries: From the Invention of Writing to the Computer Age (2009) and Stuart Murray's The Library: An Illustrated History (2009). ${ }^{7}$ James W. P. Campbell and Will Pryce contribute an architectural perspective with The Library: A World History (2013), whilst Yun Lee Too's The Idea of the Library in the Ancient World (2010) and König, Oikonomopoulou and Woolf's Ancient Libraries (2013) take us back to some of the earliest examples. ${ }^{8}$ More recently, Matthew Battles' and Jeffrey Schnapps' The Library Beyond the Book (2014) provides a whimsical, palimpsestic vision of the library to come, and Alice Crawford's edited collection The Meaning of the Library. A Cultural History (2015) offers essays from a range of disciplinary perspectives. ${ }^{9}$ Crawford's Introduction laments the recent closures of public libraries in the UK, and it is these which are the inspiration behind The Library Book (2012), a less scholarly collection of short pieces written by high profile cultural figures contributing personal perspectives on the importance of the public library. ${ }^{10}$ Finally, Alex Johnson's Improbable Libraries (2015) represents a photographic celebration of world-wide variations on traditional views of the library, from the BiblioTren project in Catalonia to a Ford Falcon repurposed to resemble a tank bringing books to the streets of Argentina. ${ }^{11}$

'The library' in the majority of these studies is represented by the most readily recognisable types - national, research, public, private -- approached in various ways: 
as material edifices set in an urban landscape, for instance; as cultural institutions subject to the power plays of states or warring factions; or as personal collections in which the owners are affectively invested. Definitions may centre on changes of support, from stelae, clay tablets, papyri, and codices to today's digital holdings and the apparently oxomoronic bookless library. Robert Darnton asserts that the 'sole purpose' of libraries 'is to preserve and diffuse knowledge', a definition by function which might be thought potentially to exclude fiction: a library is defined in Genevieve Cogman's novel The Invisible Library (2015) in terms of 'any significant store of knowledge or fiction', as if these were indeed two distinct entities. ${ }^{12}$ Battles and Schnapp push a definition of the library to its limits with their futuristic 'Accumulibrary' which 'fails to differentiate documents from things, books from periodicals from pamphlets, devices from objects' ${ }^{13}$ According to these authors we may simply need to stop seeking a singular definition: 'Does a new millennium of libraries lie beyond the millennia in which The Library was one? ${ }^{14}$ The range of possible versions of the library addressed in these works of non fiction underscores the fact that the literary corpus which will be dicussed here shares a specific vision: the library as a deliberate collection of books, mainly but not necessarily exclusively fiction, in codex form.

All published in the twenty-first century, these works of fiction are drawn from a broad range of national literatures (American, British, Russian, French, Irish, Japanese and Spanish), represent different genres, and in one case, a different medium (television). Several of them can be described as examples of 'popular fiction' or -and there is often an overlap between the two -- of world fiction, if we adopt as a rather free definition of the latter, works which travel successfully beyond their source 
culture. Set in 2021 Stéphanie Benson's crime fiction Biblio-quête (2001) opens with the murder of a historian in a new university research library. ${ }^{15}$ Two episodes of Dr Who, 'Silence in the Library' and its sequel 'Forest of the Dead' (2008), unfold in the $51^{\text {st }}$ century on a planet simply called and comprising 'The Library' ${ }^{16}$ By contrast, Carlos Ruiz Zafón's internationally best-selling trilogy La sombra del viento (2001), El juego del ángel (2008) and El prisionero del cielo (2011) takes readers back in time from the 1920s through to post Civil War Spain. As well as a bookshop and private libraries, all three texts feature the 'Cementerio de los Libros Olvidados', a mysterious haven for books which is described on several occasions as 'una gigantesca biblioteca'. ${ }^{17}$ Haruki Murakami's Kafka on the Shore (2005) has its runaway protagonist take refuge in the (fictional) Komura Memorial Library, once a private building now open to the public, a move which triggers various typically fantastical adventures including a somewhat unusual liaison with librarian Miss Saeki. ${ }^{18}$ If the latter is mysterious then the librarians who feature in Russian Booker winner Mikhael Elizarov's The Librarian (2015) are even more so. Elizarov's plot is based on the premise that a forgotten socialist realist novelist's works confer magical powers upon those who read them, a discovery which engenders the emergence of librarians as leaders of warring factions engaged in extraordinarily violent acquisition battles. ${ }^{19}$ Jasper Fforde's Thursday Next series, published between 2001 (The Eyre Affair) and 2012 (The Woman Who Died a Lot), combining fantasy, crime, satire and literary parody, features BookWorld alongside RealWorld, with the Great Library located in the former. ${ }^{20}$ In sharp contrast, Niall William's History of the Rain (2014), set in present day County Clare, focuses on the personal library of 3958 books handed down to bedridden protagonist and narrator Ruth Swain by her father. ${ }^{21}$ Finally, J. J. Abrams' and Doug Horst's $S$. (2013) takes the material form of a facsimile library 
book entitled Ship of Theseus, published in 1949 and written by fictitious author V. M. Straka, the margins of which are heavily annotated by students Jen and Eric. ${ }^{22}$

\section{For the love of books: handling the material and the digital}

Starting from an uncomplicated and perhaps unsurprising observation, these are works which feature bibliophiles of various hues. In the case of the 'Dr Who' episodes, for instance, it emerges that The Library was built for a little girl who 'loved books more than everything'. In Ruiz Zafón's fictional world liking or disliking books is indicative of moral status: bibliophiles include protagonists Daniel Sempere and Fermín Romero de Torres. Penélope Aldaya, whom author Julián Carax first meets and falls in love with in the Aldaya library, is 'un poco tocada del ala. Se pasa el día leyendo' (239) ['a bit nutty. She spends all day reading', 173], unlike her brother Jorge for whom 'Los libros son aburridos' (238) ['Books are boring', 173]. Political mercenary and torturer Chief Inspector Francisco Javier Fumero, it goes without saying, despises books, as does David Martín's abusive father in El juego del ángel. William's protagonist recalls how she was taken to Ennis library as a child and was thereafter hooked on books (History of the Rain, 62); Murakami's Kafka explains how his bibliophilia first emerged when he rode his bike to the local public library after school (Kafka, 34). Like many a bibliophile Kafka articulates the escapist pleasures of reading: 'the real world evaporates. I'm alone, inside the world of the story. My favourite feeling in the world' (61). Fforde's Thursday Next, when asked if she is a librarian, replies 'Let's just say I'm really into books' (First Amongst Sequels, 175), a comment which could equally apply to students of literature Jen and Eric in $S$., but which in the case of Fforde's heroine is more than just a metaphor. 
The bibliophile protagonist as device points to an implied author, and intended reader, perhaps, of similar bent, but these fictional texts do more than just flag up a love of libraries: they almost all insist on the importance of the codex as material artefact. The main exception is Ruiz Zafón's trilogy of historical novels, set prior to a critical development: the rise of digitisation. ${ }^{23}$ Alongside the cluster of histories and studies mentioned above, works addressing digitisation and its potential effects on libraries also began to emerge in the new millennium, including, perhaps most notably, Nicholson Baker's polemical Double Fold. Libraries and the Assault on Paper (2001) and Robert Darnton's The Case for Books (2009). ${ }^{24}$ Writing in the early days of support change Baker takes issue specifically with the transfer of books and newspapers to microfilm in terms of risks (text and images may be omitted or corrupted; much is lost in the absence of original pagination; if originals are thrown away there is no going back), lack of necessity (paper has much greater longevity than has been claimed) and cost (literal and cultural), laying much of the blame on libraries and librarians. Robert Darnton is primarily concerned with the controversies and legal battles which have accompanied the Google Book Search project and the company's subsequent bid to compile what he calls 'a gigantic digital library', a creation that would become 'the world's greatest library, bigger by far than anything dreamed of since the library of Alexandria'. ${ }^{25}$ Although Darnton shares many of Baker's fears concerning the risks of digitisation, his main objection is to what he regards as the potential commercialisation and privatisation of knowledge. ${ }^{26}$ Baker is resolutely onesided and polemical in his approach; Darnton is more even-handed: but what sort of representations of the digital can be accommodated by literary texts whose vision of the library centres on the codex? 
Darnton's expressed sensitivity to the sensory qualities of paper (he refers approvingly to French students' resisting the purchase of 'odorless electronic books' $)^{27}$ would certainly be appreciated by Ruth Swain, the narrator of Williams' History of the Rain, who lovingly describes the physical characteristics of individual books as she reads her way through her father's library: a Penguin Classics edition of Oliver Twist 'smells amazingly like toast' (18); a Bible is 'black and soft with the kind of feather-light pages they only use in bibles' (62). In a literalisation of the familiar metaphor which has readers 'devour books', Swain describes leather-bound classics as her first teethers: 'I gummed and smelled my way into Literature' (53). History of the Rain establishes an unequivocal material / digital opposition, with its narrator insisting 'I'm not an e-person or an iPerson' (62) and referring both ironically and wistfully to 'old-style finger and blackened-wet-thumb googling' (51). Williams reminds us of the sheer physicality of the reading act. A book for Williams' narrator has value as 'a thing not vague or virtual but something you can hold and feel and smell' (353). In terms of the corpus, this is the least ambivalent representation of digitisation. A binary is constructed with no reasons proffered for the pro-paper sentiment; as the narrator puts it herself: 'You either get it or you don't' (62).

In fact, an oppositional construction which sets the card and paper codex against a digital support, if it is presented - as is the case with Williams' narrator - in terms of material versus virtual and somehow immaterial, is misleading (though note that the French term 'dématérialisation' is currently used as a synonym for 'numérisation'). All codices now involve digital technology to some extent, whether in the form of barcoding, the printing process or marketing strategies, not to mention their availability as e-books (as is, of course, the case for History of the Rain itself). The 
obverse is also true. One has only to think of metaphors drawn from the material world used in the context of digital technologies, from the 'desktop', 'folders' and 'emptying the trash' to the enduring concept of the page itself. And as James Gleick reminds us, writing here specifically on information stored in the apparently immaterial 'cloud', digital technologies depend upon very tangible and visible infrastructures: 'Server farms proliferate in unmarked brick buildings and steel complexes [...] miles of hollow floors, diesel generators, cooling towers, seven-foot intake fans, and aluminium chimney stacks'. ${ }^{28}$

History of the Rain is, however, an exception: most of the works in the corpus avoid a straightforward material / digital polarity, taking advantage of the imaginative possibilities open to fiction to produce more complex, often hybridised representations. Doug Abrams has described $S$. as 'a celebration of the analog, of the physical object'. ${ }^{29}$ Rather than a narrator lauding the material object as is the case with Williams, the authors of $S$. ensure that it is we as readers who are constantly aware of it. The book-object comes in a presentation box with a paper seal which must be broken -- an unrepeatable physical act which alters the object in a way that keystrokes cannot definitively alter a digital text -- bearing the names of Dorst and Abrams, the title, publisher's blurb and barcode. Inside the box is a facsimile library book entitled Ship of Theseus (1949) with a slightly battered cover and yellowed pages, the classmark 813.54 STR on its spine, a red stamp 'BOOK FOR LOAN' on the inside front cover, with a further stamp identifying it as 'Property of Laguna Verde H. S. Library'. The inside back cover bears the familiar (to readers of a certain age) date-stamped record of loans. ${ }^{30}$ Ship of Theseus also comes with a number of inserts - including a scribbled-upon paper napkin, postcards and letters -- which 
inevitably and alarmingly fall out during the reading process, prompting us on each occasion to focus on the physical object we are handling. The replicated handwritten notes which fill the margins of the book, made by literature students Jen and Eric, make the reading of the text a matter of choices: do we ignore the marginalia and focus on Straka's story, or attempt to read each page in full (text and marginal notes)? And do we read all the notes at once, or pay heed to the colour coding indicating at least four different time periods of inscription? For all that it directs readers' attention to the material artefact, by offering us multiple possible pathways, $S$. mimics an interactive online book; this is an ersatz digital text in codex form. Further subverting a material / digital opposition, the authors of $S$. fully exploit online resources, offering on a dedicated website not only tips on how to read the work, but additional text - for instance an alternative final chapter for Ship of Theseus - available only in digital form. $^{31}$

In Fforde's literary universe emphasis on the material artefact is played out within the generous parameters of the fantasy genre, specifically via the concept of two coexisting diegetic worlds. A few, gifted characters from RealWorld (equivalent to our reality) have the capacity to enter BookWorld, whose own characters on occasion migrate from book to book (something of a literalised variation on Alberto Manguel's dream of a narrative stream in which 'the hero of The Castle would embark on the Pequod in search of the Holy Grail'. $)^{32}$ The 'stuff' of books is constantly brought to our attention, less in terms of paper and card and more in a material vision of text: Fforde's BookWorld comes complete with ships embarked on the Text Sea with 'scrawltrawlers [...] at their moorings' selling off 'the day's wordcatch' (Well of Lost Plots, 264), whilst BookWorld maps are drawn up using the handy ISBN Positioning 
System (Well of Lost Plots, 307). Fforde happily hybridises the material and the digital. The move away from paper support to online text is treated with deliberate anachronistic humour: references to the update from ClayTablet V2.1 to SCROLL (through to version SCROLL V3.5) to BOOK and its several iterations (Well of Lost Plots, 110-11) serve as a reminder that changes in material support are nothing new. In similar combinatory mode, the online 'Fforde Book Upgrade Centre' invites readers to report errors in the novels (typos, inconsistencies) and instructs them on how to 'upgrade' their copies: by ensuring that they are running BOOK 8.3 then entering the corrections 'using a fine black pen'. 33

Digitisation nonetheless comes with risks in the literary universe. That which critics such as Baker and Darnton express in terms of possible error can be dramatised to become criminal manipulation. Fforde's fantasy series' habitual criminal, the monolithic company Goliath (more than somewhat reminiscient of Google, though predating it), seeks to control the contents of books using new software: 'That's the beauty of UltraWord ${ }^{\mathrm{TM}}[\ldots]$ We have the Great Library within our control - with the source text at our fingertips can do anything. History will be good to us because we are the ones who shall write it!' (Well of Lost Plots, 343). A similar, though more historically focused approach plays out in Benson's crime fiction Biblio-quête, which sees a historian murdered in Lyon's Nouvelle Bibliothèque Raymond-Barre when he discovers that the company responsible for the digitisation of library print book holdings and newspaper archives across Europe has been tampering with text in order to exclude all references to the Holocaust. Benson's text is not by any means antitechnology: the crime is solved with the aid of a futuristic sleuthing computer programme, and a shift into historian Joesandi's point of view demonstrates his 
appreciation of the need for a sophisticated computerised catalogue: 'le système nerveux central d'où partaient tous les flux d'informations et de références sans lesquelles cette vaste structure n'était qu'un grenier rempli de vieux livres' (15) ['the central nervous system from which all data and references flowed and without which this vast structure was nothing but an attic full of old books'], the latter being exactly what we find in Williams' History of the Rain.

Of course catalogues can also be manipulated. Elizarov's narrator in The Librarian states that 'during computerization', all data on Gromov, the propagandist author whose works confer magical properties upon their readers, were deliberately not entered into the online system, thereby ensuring that the author 'formally disappeared' (19). In what can be read as a series of indirect references to digitisation, paradoxically expressed in terms of the analogue object, it is revealed that for magic to happen key conditions must be observed. First, books must be read with absolute concentration and in one sitting - surely a jibe at both the flagging attention span and snippet-centred reading mode often invoked by critics of online reading. Textual omissions also block the power of the book: "“But it [the Book of Meaning] didn't work [...]". She abruptly opened the book at the back flyleaf and scraped her nail across a scuffed stripe with traces of glue on it in the middle of the page. "But now there isn't any insert..."' (339). Although once more described in terms of the material codex, anxieties about missing text takes us back to the much discussed risks of digitisation. As was the case with Fforde and to an extent Benson, we find in The Librarian not a polarisation of the material and the digital, but one expressed in terms of the other. It is made clear that only the printed artefact has an effect on readers: 'the typeface, the paper, the layout, the format' are all crucial (186). At same time, 
however, books are described metaphorically in terms of computing technology: 'Each program-Book is equipped with a resident subroutine - a coded subtext that is activated when the Two Conditions of intent reading are met' (185).

Various means of avoiding a simple and simplistic material / digital opposition are thus adopted throughout the corpus, with arguably the most extreme variant attributable to the 'Dr Who' episodes, where digitisation is given a particularly uncanny twist. When users of The Library come under attack from an alien life form, the mainframe computer CAL uploads and saves them to a virtual world. In this library, in other words, it is the humans and not the books who are digitised. Reminders of the materiality of texts also take an extreme form: the Vashta Nerada species attack because their natural forest habitat has been destroyed, pulped to produce endless stacks of codices. Bibliophilia, when associated with the material artefact, can have its drawbacks.

\section{Old places, new metaphors}

In her 'After the Archive' Carolyn Steedman reflects on what she sees as historians' lack of interest in the 'archival turn' and insists on the need to differentiate between 'the archive as an idea' and as 'a place'. ${ }^{4}$ The texts in the literary corpus under discussion here represent both a very 'real' library-as-place and a metaphorical library-as-idea. In fact, they do more than just represent the physical spaces of libraries: the 'realness' and 'placeness' is in each case brought to the reader's attention. Murakami's Komura Memorial Library as material entity is emphasised via detailed description: the reading room has a comfortable sofa and 'white curtain rustling softly in the air' (39); several pages are given over to an account of a guided 
tour providing both a history of the building and information about interior design, down to the nature of the carving on wooden panels, or an ebony banister 'so polished it looks as though you'll leave a mark if you touch it' (43). The material reality of the library is further stressed when the narrator explicitly addresses its ontological status: 'I'd always thought of it as a secret, imaginary place, and can barely believe that is actually exists' (39, author's emphasis). ${ }^{35}$ Fforde's narrator replicates this pattern, stating: 'I had always thought that the Library was created conceptually to contain the books and had no use or existence outside that' (Well of Lost Plots, 259). Though the notion of the real is somewhat fluid in Fforde's fictional universe, here too the Great Library of BookWorld has distinct material characteristics including a certain number of floors, reading desks, marble busts and green-shaded brass reading lamps (Well of Lost Plots, 70; First Among Sequels, 53). In the case of 'Dr Who' placeness is highlighted by the apparent clash of advanced technology and the futuristic $\left(51^{\text {st }}\right.$ century) temporal setting with the same representation of old-style codices in stacks and individual reading lights (parts of these episodes were filmed in the Old Swansea Central Library). Williams' History of the Rain features a private collection, so the library is not stored in a discrete building, but the specificity of physical location is nonetheless recorded here too: 'She looks around at them, in proper terms my father's library, but really just the enormous collection of books he accumulated which has now been brought up to my room and stacked from the floor to where the angle of the skylight cuts them off' (16). The physical space of the library in $S$. is foregrounded by both the metonymic facsimile library book and the character Jen's repeated references to the library in which she works, a space which begins as a haven but becomes one where people are 'pretending to read / study / browse / copy / etc' but apparently watching her (230, marginal note). Finally, the material space of Ruiz Zafón's 
'Cementerio de los Libros Olvidados' gains presence via references to actual streets in Barcelona which must be navigated to locate it (through the Ramblas de Santa Mónica and into the Calle Arco del Teatro). Here too, physical detail comes in abundant form, from the high glass dome and marble staircase (La sombra, 11) to the massive and complicated lock on the front door (La sombra, 78).

What emerges quite clearly is that these texts offer up a nostalgic construct of the library. These represented material spaces hark back not just to libraries of the predigital era, but to a period (the mid 1980s at the latest) before public library holdings diversified to include, for instance, film and music, transforming codex-centred reading and study spaces into multimedia centres or médiathèques. These representations are certainly far removed from what James Gleick recently referred to as the library as 'Starbucks wannabe', popular primarily for its free Internet access. ${ }^{36}$ Solid, tangible places, such literary libraries can thus be set against the delocalisation and dematerialisation associated with the internet and digital texts. At the same time as they represent a nostalgic, retrospective gaze, however, these works of fiction also acknowledge the new when it comes to their representation of the conceptualised library-as-idea. A range of myths and tropes have long been associated with the library (order and disorder; darkness and light; exclusion and inclusion; the blind librarian, etc), but just three will be discussed here: the myth of the universal library; the destruction of the library; the library and / as memory. Here too the literary texts show consistency in their reworking of these motifs in the context of the digital age.

The universal library is solidly implanted in the secondary literature, evoked most often in relation to the historical example of the Library at Alexandria: 'the first 
library with universal aspirations'; the library 'where the universe itself found its worded reflection'; a library which has become the shorthand for all-encompassing 'massive, Alexandrian' - acquisitional intent. ${ }^{37}$ This mythical, 'total', library is also closely associated with a fictional avatar, Borges' 'La biblioteca de Babel' (1941), but does it survive in the library fiction of the new millennium? The answer is yes, but in modified form. Ruiz Zafón certainly seems to have had the universal library in mind. His Keeper of the 'Cementerio de los Libros Olvidados' is described as 'a medio camino entre Caronte y el bibliotecario de Alejandría' (La sombra, 78) ['somewhere between Charon and the librarian at Alexandria', 53]; the 'Cementerio' itself is traversed by 'un babel de túneles, pasarelas y puentes' (El juego, 653) [the English translation opts for the Borgesian echo of 'babel' rather a more neutral 'chaos' or 'confusion': 'a babel of tunnels, footbridges and bridges', Angel, 493]. It is a labyrinthine library 'de geometría imposible', a further nod to Borges' library with its crazy hexagonal galleries, and to the recurring Borgesian labyrinth motif. Ruiz Zafón's is not, however, a library with universal aspirations. It is a place for forgotten books, those which are no longer read. The desire to amass everything has been replaced by anxieties about the preservation of just a small part of the whole.

A similar diminution of ambition can be found elsewhere. Operating in the world of the fantastic, Fforde has the writerly freedom to make real the mythical model, and indeed his 'Great Library' includes a copy of ‘every book that's been written' and 'that will ever be written'. Even in the world of fantasy, however, the notion is gently undermined by a humorous hyperbolic aside: 'and a few others besides' (Lost in a Good Book, 164). The genre of science fiction could also facilitate the depiction of a universal library, but the 'Dr Who' episodes represent a similarly downgraded 
version. Borges' 'Library of Babel' opens with the well-known words 'El universo (que otros llaman la Biblioteca)' ['The universe (which others call the Library)'], before going on to describe a library that has always existed and includes everything ever written, past, present and future. The Library of the 'Dr Who' episodes is somewhat reined back: it is not a universe but a mere planet; it has existed only for several generations and not 'ab aeternitate', as Borges' narrating librarian would have it, and although its holdings extend to 'every book ever written', it apparently cannot accommodate future publications. ${ }^{38}$

In all three cases universalist ambition has been quashed, and although no explicit reasons for such subversive evocations of the universal library are provided, the answer lies, I would suggest, not just in the sheer mass of knowledge (or 'information' as we may now conceive of it) available for potential acquisition today, making universalist aspirations ever less realisable, but also, and especially, to the form in which we are most likely to access and store it today: digitally. As Lev Manovich notes, 'the hypertext of the World Wide Web leads the reader from one text to another ad infinitum', though as he points out, the internet lacks the necessary ordering system of a library. ${ }^{39}$ According to Gleick, it is Wikipedians who now 'consider themselves as the Great Library's heirs, their mission the gathering of all recorded knowledge'. ${ }^{40}$ Or as Alberto Manguel puts it, in less sanguine mode: 'If the Library of Alexandria was the emblem of our ambition of omnipotence, the Web is the emblem of our ambition of omnipresence; the library that contained everything has become the library that contains anything'. ${ }^{41}$ The universal library, in other words, has been doubly displaced -- dissociated from the physical place of the library and delocalised into the digital realm of the internet. 
The Library at Alexandria is identified not just with its acquisitions programme but also with its destruction, which has gained near mythical status. Just as the notion of the universal library was treated differently in the contemporary literary corpus, so too libraries emerge rather more intact than might have been expected given not just the on-going critical interest in their destruction, ${ }^{42}$ but equally, the example set by influential literary predecessors: Eco's monastic library in Il nome della rosa (1980) and sinologist Peter Kien's private collection in Canetti's Die Blendung (1935), for instance, both go up in flames. Destruction of the library by fire, the method most strongly ingrained in the cultural imaginary, is alluded to in two of the literary texts only to be decoupled from the contemporary world in each case. Fforde employs his usual anachronistic humour -- “"Do you know what happened when they tried to upgrade SCROLL" said Bradshaw? "The system conflict wiped the entire library at Alexandria - they had to torch the lot to stop it spreading"” (The Well of Lost Plots, 110) - but his own creation, the Great Library, remains unscathed. In Dorst and Abram's $S$. library conflagrations are firmly located in the spatio-temporal world of the Ship of Theseus (1949) or indeed set back to an even earlier era: an insert (between pages 20 and 21) records the destruction of a monastic library in the eighteenth century; it is said that an enemy agent seeking to kill S. had formerly 'torched the library at Leuwen' (324). The library in the contemporary world of students Jen and Eric stays standing.

In two other cases, destruction threatens but is ultimately avoided. The narrator's inherited library in Williams' History of the Rain suffers various near misses due to accident rather than intent, remaining 'a library of books burned and drowned but 
undestroyed' (352). In Benson's Biblio-quête a fire (causing minimal damage) is set in the library by a bibliophile seeking to draw attention to the right-wing agenda at work behind the scenes. ${ }^{43}$ Finally, in the cases of Murakami and Ruiz Zafón, book burning is perpetrated by fictional authors: both Julián Carax and Miss Saeti burn their own writings (or order them to be burned in the latter case) as a symbolic means of erasing their own past. In these literary works libraries are no longer imagined foreshadowed by their own end, perhaps in part because anxieties about digitisation destruction by another means? - prevail, but equally, I suggest, because these libraries function as fantasms, pure constructs which, precisely because they no longer exist in our reality, must maintain their unscathed nostalgic textual integrity.

Contemporary literary libraries are neither universal nor do they readily succumb to external forces, but are they still linked metaphorically to the human mind? Battles and Schnapp comment on 'the metaphorical power of the library to denominate the properties of intelligence, memory, and accumulation; a "walking library" is someone whose knowledge we find capacious and trustworthy' ${ }^{44}$ The very first line of Stuart Murray's The Library: An Illustrated History describes libraries as 'the collected memory of the human race' (unpaginated). In an age when memory is increasingly thought of in terms of bits and bytes rather than neural pathways, and indeed when the internet is regarded as a threat to our own cognitive capacities, it is to be expected that the familiar metaphorical link is, if not severed, then at least given something of a tweak.

Memory in the fictional library world of 'Dr Who' is dissociated from the codices which line the shelves and stacks present in so many shots. Instead, it is CAL the 
computer, with its capacious memory, that 'saves' the endangered library users to a virtual world. CAL, it is revealed, is an acronym for 'Charlotte Abigail Lux', the little girl who loved books and whose mind was uploaded into the library computer when she contracted a fatal illness. This is not a metaphorical mind-library interface but a real one. By the close of 'Forest of the Dead' CAL's future is uncertain and the books seem destined to remain unread. Probing the metaphor linking the library to the human mind is also a feature of Murakami's Kafka on the Shore. On the one hand the protagonist is told that 'The library handles memories' (473); the character Nakata, who has no memories and cannot read, describes himself as 'like a library without a single book' (329); library assistant Oshima explains that 'inside our heads [...] there's a little room where we store [those] memories. A room like the stacks in this library' (501). In spite of what seems to be a familiar trope, memory in these cases is not cultural - the metaphor does not embrace the sum of human or national knowledge -- but is instead entirely personal and individual. As was the case with the literal mind-library interface represented by CAL in Dr Who, so here too metaphor seems to be replaced by a real (if unexplained) connection: when Kafka asks 'You mean I'm going to be working at the library?', he is corrected and told - three times in the space of two pages - that he will rather 'be a part of the library' (166-67, author's emphasis). Towards the close of the text Oshima further insists enigmatically that 'for you and me this library alone is no metaphor. It's always just this library' (530).

The library no longer functions as a metaphorical repository of cultural memory in either the 'Dr Who' episodes or Murakami's Kafka on the Shore. In the case of both Biblio-quête and Elizarov's The Librarian this decoupling is given a specific 
historical context. A student in Biblio-quête speculates that fire-setting historian Joesandi may have acted out of frustration at the diminution of his own capacities: 'un moment de folie l'aurait poussé à détruire le symbole par excellence de la mémoire: une bibliothèque' (115) ['maybe in a moment of madness he set out to destroy the symbol of memory: the library']. But the student is wrong in both her assessment of the perpetrator and her symbolic attribution. It is Joesandi's prodigious memory ('Il avait une mémoire phénoménale [...] Il ne se trompait jamais’ (101) ['He had a phenomenal memory [...] He never made mistakes']) which alerts him to the work of the digitising criminals as he recalls the original, undoctored passages from codices and print articles. Computers, meanwhile, are also subject to worrisome vulnerabilities: Joesandi's has become 'parfaitement amnésique' (116), its memory wiped by Holocaust deniers.

This potential for libraries to be linked to corrupted or false memory is also represented in Elizarov's The Librarian. The 'reading room' headed up by librariannarrator Alexei is grouped around a specific magical work: the Book of Memory (aka fictional socialist realist Gromov's The Quiet Grass, published 1977), the reading of which affords members a deep sense of joy and purpose. Alexei alone realises that the Book of Memory confers 'a gift of deception' (61), conjuring up 'a mirage' (261) which dazzles with its fake happy childhood but also with richly sensory visions of a rose-tinted Soviet era. Alexei's reading experience is conveyed by an unbroken stream of consciousness running over more than a page and a half and recording a bombardment of memories from earlier decades, ranging from the Young Pioneers to figure skater Irena Rodnina to chewing gum (199-200), memories described by him as 'false visions'. Critics have been divided in their assessment of The Librarian, with 
some regarding it as nostalgic for the Soviet era, but the narrative voice maintains a degree of self-reflexive irony throughout, whilst acknowledging the attractions of nostalgia. As Alexei remarks, with typical self-reflexive distance, perhaps false happiness is better than none at all: 'After all, in my genuine childhood I believed absolutely that the state which was eulogized in all the books, films and plays was the reality in which I lived' (405). Either way the reading rooms and libraries which put their faith in the Book of Memory are destined to be duped.

Significantly, only Ruiz Zafón's historical - and thus pre-digital -- tales continue to represent the library as a haven for cultural and national memory. Surrounded by the volumes in the 'Cementerio de los Libros Olvidados' protagonist Daniel despairs of 'el mundo que palpitaba fuera de aquellos muros perdía la memoria sin darse cuenta día tras día, sintiéndose más sabio cuanto más olvidaba' (La sombra, p. 89) ['the world that throbbed outside the library [which] seemed to be losing its memory, day after day, unknowingly, feeling all the wiser the more it forgot' 61]. With varying inflections, critics generally agree that the 'Cementerio' represents a symbol for Spain's forgotten, or repressed (in both sense of the term) past: the silence surrounding the Civil War, the erasure of Republican identity under Franco, the Pacto del Olvido and Transition to democracy. ${ }^{45}$ Historical detail in the trilogy is, however, low key, with a strong emphasis on the personal lives of individuals. According to Robert Ellis: 'the Ruiz Zafón text depoliticizes history, transmuting the violence of the war into a personal vendetta rooted in psychological trauma' ${ }^{46}$ Not just $L a$ sombra del viento but the trilogy is indeed steeped in representations of familial trauma and dysfunction: both Daniel of La sombra and David Martín of El juego del ángel, for instance, lose their mothers at a young age; Martín and Julían Carax face 
abusive fathers or father figures; Carax has an incestuous relationship with his halfsister who dies bearing their stillborn child. Such is perhaps only to be expected from neo-gothic texts which revel in their own melodrama. Strikingly, though, family traumas are in evidence throughout the literary corpus.

\section{Dysfunctional Families and (Un)heimlich spaces}

In the case of 'Dr Who', the father of a dying child (Charlotte Abigail Lux aka CAL) builds her a library -- indeed builds her into one; meanwhile, the Doctor's companion, Donna, is uploaded to a virtual reality of happy families (one husband and two children) only to discover that this is not the real world and so must be renounced. Like Charlotte Abigail, Ruth Swain, the narrator of History of the Rain is dying and receives a library from her father, passed on in this case down three generations of male heirs; Ruth Swain's twin brother, Aeney, drowned in the river, his body never found (where, one wonders, is the body of Charlotte Abigail Lux). Murakami's protagonist apparently kills his father, sleeps with his (librarian) mother, Miss Saeki, and quite possibly (like Ruiz Zafón's Julían Carax) with his sister for good measure. Elizarov's cast is rather less dysfunctional, but here too the narrator inherits his library from a male relative (his uncle, the black sheep of the family) and gains a new, metaphorical family in the form of his 'reading room'. Dorst and Abram's student character Eric, who reflects that 'looks like everyone's worried about their fathers' (438, marginal note), carries the blame for the death of his uncle; the family of fellow annotator Jen has been equally dysfunctional since the death of her baby brother. Estranged from his mother, researcher and historian Marc Floric in Benson's Biblioquête is carrying on the work of his father, who committed suicide twenty years earlier. Fforde's Thursday Next series is rather more light-hearted but even here 
families can be problematic, not least because Thursday's father has been deleted from history by the Chronoguard.

It is not my aim or intention to carry out an analysis of these familial strains and faultlines here, though there is certainly scope for one -- the start, perhaps, of an archive-rivalling scholarly attention paid to the neglected sibling, the library. What is clear is that libraries in all of these texts are connected with (highly gendered) psychic dramas, be it in the form of oedipal conflicts (desired mothers, abusive fathers), ${ }^{47}$ family romances (dead siblings, uncles, surrogate families), good and bad fathers, tropes of legacy or trans-generational trauma. The material, codex-filled library-asspace represented, or fantasised, in these works is where Ruiz Zafón's Daniel is taken to help overcome the loss of his mother and where Williams' narrator hopes to find her father. Inscribing a library book in a common cause which allows Abrams' and Dorst's troubled students to free themselves from their familial traumas, whilst his time in the Komura Memorial Library allows Murakami's Kafka to work through his oedipal anxieties. Libraries are heimlich spaces, psychic second homes. These are places 'donde los libros nunca mueren y donde nadie puede destruirlos' (Juego, 56) ['where books never die and nobody can destroy them', Angel 38]: replace 'books' by 'people' and one aspect of the fantasy is clear. As Freud points out, however, the heimlich space is also the space of the concealed, of what is kept within the family and out of sight: the missing body of Charlotte Abigail Lux, the fate of Aeney Swain, student Eric's dead uncle and Kafka's missing mother.

Both protecting and concealing, libraries can be conceived as complex, threshold spaces. Affectively linked to childhood, they are very different from the adult-centred 
world of the archive. 'It started before the time they'd let us walk to school. But for some reason we were allowed to do this [cycle to the public library]. We were eight or nine years old [...]'; 'The librarians themselves were fearsome, yet kind, allowing the child me to take out adult books' ${ }^{48}$ Ali Smith's recent collection, Public Library and other stories, echoes a motif which runs throughout the literary corpus: the child's first trip to the library, often taking place at a liminal age between childhood and adolescence; old enough to experience troubling intimations of both sex and death without necessarily fully comprehending either. ${ }^{49}$ Libraries are also public spaces that promote private practices: books may be borrowed and taken home, or read in situ; either way, reading the codex remains a solitary experience. The physical library spaces so emphatically represented in these literary texts and the emphasis on the book as material object can be read as nostalgic, perhaps unconscious, gestures not just towards a lost era, but also a lost childhood.

But the texts do more than look longingly to an irretrievable past. Part of the digital era, they acknowledge the reality of new technologies, sometimes with humour, sometimes with a view to reminding us that each age has brought and will bring its own changes to the library and its contents, and sometimes in order to flag up some of the very real risks associated with digitisation now and in the future. These texts are first generation post-digital works. As such they provide the most recent page in a history of library fiction. It may be that not long from now the material codex and old-style library will be deleted from the popular imaginary, and a new mode of library fiction will emerge: but will the bookless library it may represent still be a 'library', and will the digital texts still be 'books'? 
(Word count: main text, 7463; notes, 1211)

${ }^{1}$ Ben Hutchinson and Shane Weller, 'Archive Time', Comparative Critical Studies 8.2-3 (2011), pp. 133-53 [133].

${ }^{2}$ Derrida, Mal d'archive (Galilée, 1995), trans. E. Prenowitz, Archive Fever (Univ. Chicago Press, 1995). Foucault's most commonly cited material on the archive comes from his L'Archéologie du savoir (Gallimard, 1969) though his archaeological and genealogical theorisations developed and expanded over the years.

${ }^{3}$ Hutchinson and Weller, p. 133.

${ }^{4}$ Marlene Manoff, 'Theories of the Archive Across the Disciplines', portal: Libraries and the Academy 4.1 (2004) pp. 9-25 [10].

${ }^{5}$ Matthew Battles, Library. An Unquiet History (London: Vintage, 2004); Alberto Manguel, The Library at Night (New Haven \& London: Yale UP, 2006). See also Jean Marie Goulemot, L'Amour des bibliothèques (Paris: Seuil, 2006).

${ }^{6}$ Battles, Unquiet History, p. 20. Konstantinos Staikos, The History of the Library in Western Civilisation, 6 vols. (New Castle, Del.: Oak Knoll Press, 2004-13).

${ }^{7}$ Fred Lerner, The Story of Libraries: From the Invention of Writing to the Computer Age (London: Continuum, 2009); Stuart Murray, The Library: An Illustrated History (Skyhorse Publishing / American Library Association: Chicago, 2009).

${ }^{8}$ James W. P. Campbell and Will Pryce (photographer), The Library: A World History (Thames \& Hudson, 2013); Yun Lee Too, The Idea of the Library in the Ancient World (Oxford: OUP, 2010); König, Oikonomopoulou and Woolf (eds), Ancient Libraries (Cambridge: Cambridge UP, 2010).

${ }^{9}$ Matthew Battles \& Jeffrey T Schnapp, The Library Beyond the Book (Cambridge, Mass.: Harvard UP, 2014); Alice Crawford (ed.) The Meaning of the Library. A Cultural History (Princeton: Princeton UP, 2015). 
${ }^{10}$ Rebecca Gray (ed.), The Library Book (London: Profile Books, 2012).

${ }^{11}$ Alex Johnson, Improbable Libraries (London: Thames \& Hudson, 2015). The BiblioTren project allowed commuters on the Catalonia railway system to download works ( $40 \%$ of them fiction) via barcodes on train windows accessed using mobile devices, p. 22.

${ }^{12}$ Robert Darnton, The Case for Books (New York: PublicAffairs, 2009), p. x; Genevieve Cogman, The Invisible Library (London: Tor, 2015), p. 130.

${ }^{13}$ Battles and Schnapp, The Library Beyond the Book, p. 84.

${ }^{14}$ Ibid. p. 30 .

${ }^{15}$ Stéphanie Benson, Biblio-quête (Éditions du Seuil, 2001).

16 'Dr Who', Season 4, Episodes 8 and 9; writer Steven Moffat, director Euros Lyn.

${ }^{17}$ La sombra del viento (Planeta, 2001), El juego del ángel (Planeta, 2008) and El prisionero del cielo (Planeta, 2011). Translations are taken from The Shadow of the Wind (Phoenix, 2004), and The Angel's Game (Phoenix, 2009), both translated by Lucia Grave.

${ }^{18}$ Haruki Murakami, Kafka on the Shore (London: Harvill Press, 2005; original publication 2002), trans. Philip Gabriel.

${ }^{19}$ Mikhael Elizarov, The Librarian (London: Pushkin Press, 2015; original publication 2007), trans. Andrew Bromfield.

${ }^{20}$ Jasper Fforde: The Eyre Affair (2001); Lost in a Good Book (2002); The Well of Lost Plots (2003); Something Rotten (2004); First Among Sequels (2007); One of our Thursdays is Missing (2011); The Woman who Died a Lot (2012); all texts published by Hodder \& Stoughton, London.

${ }^{21}$ Niall Williams, History of the Rain (London: Bloomsbury, 2014).

22 J. J. Abrams \& Doug Dorst, S. (London: Mulholland Books, 2013). 
${ }^{23}$ The narrator of Ruiz Zafón's La sombra del viento does report that 'el arte de leer se está muriendo muy lentamente' (546) ['the art of reading is slowly dying', 399], the threat of technology represented not by digitisation but television and a growing consumer culture: by the late 1960s the Aldaya library has become the boardroom of an advertising agency.

${ }^{24}$ Nicholson Baker, Double Fold. Libraries and the Assault on Paper (New York: Random House, 2001); Robert Darnton, The Case for Books (New York:

PublicAffairs, 2009).

${ }^{25}$ The Case for Books, pp. xix and ix.

${ }^{26}$ Motivated by the Google Books project Darnton was instrumental in setting up the free access Digital Public Library of America. For other responses to Google's project, see Jean-Noël Jeanneney, Quand Google défie l'Europe. Playdoyer pour un sursaut (Mille et une nuits: 2005) and Lucien X. Polastron, La Grande Numérisation. Y a-t-il une pensée après le papier? (Denöel, 2006).

${ }^{27}$ The Case for Books, p. 39.

${ }^{28}$ James Gleick, The Information (London: Fourth Estate, 2011), p. 96.

${ }^{29}$ Joshua Rothman, 'The Story of "S.”: Talking with J. J. Abrams and Doug Dorst', The New Yorker, 23 November 2013, http://www.newyorker.com/books/pageturner/the-story-of-s-talking-with-j-j-abrams-and-doug-dorst. For another facsimile library book see Murakami's children's novella The Strange Library (London: Harvill Secker, 2014; trans. Ted Goosen, originally published 2005).

${ }^{30}$ The recreation of a 1949 text cannot be absolute: the miniscule print on the inside back cover includes 2013 copyright details and references to websites.

31 'Thoughts on “S” by J. J. Abrams and Doug Dorst', https://whoisstraka.wordpress.com/. 
${ }^{32}$ Manguel, The Library at Night, p. 63.

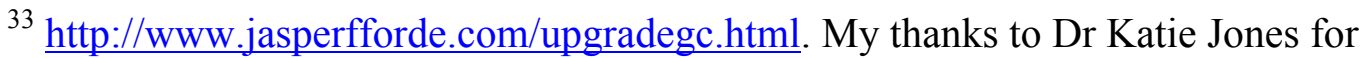
drawing my attention to this feature of the website.

${ }^{34}$ Carolyn Steedman, 'After the Archive', Comparative Critical Studies 8.2-3 (2011) pp. 321-40.

${ }^{35}$ The real building supposedly providing the blueprint for the Komura Memorial Library has been tracked down by Murakami fans. See http://ignition.co/189 and http://ajw.asahi.com/article/behind news/people/AJ201406090003

${ }^{36}$ James Gleick, 'What Libraries Can (Still) Do', New York Review of Books, 26 October 2015: http://www.nybooks.com/blogs/nyrblog/2015/oct/26/what-librariescan-still-do-bibliotech/

${ }^{37}$ Battles, Unquiet History, p. 30; Manguel, The Library at Night. p. 24; Crawford, The Meaning of the Library, p. xxv.

${ }^{38}$ For a different futuristic take on the subject see Jon Thiem's tongue-in-cheek 'Myths of the Universal Library: From Alexandria to the Postmodern Age', which is dated 2059, the Universal Library having come into existence in 2039. The Serials Librarian 26.1 (1995) pp. 63-74.

${ }^{39}$ Lev Manovich, The Language of the New Media (Cambridge, Mass.: MIT Press, 2002), p. 77.

${ }^{40}$ Gleick, The Information, p. 379.

${ }^{41}$ Manguel, The Library at Night, p. 322.

${ }^{42}$ Contributing further to signs of new millennium critical interest in the library, two recent studies bring the history of destruction up to date: Lucien Polastron, Livres en feu. Histoire de la destruction sans fin des bibliothèques (Denoël: 2004), Rebecca 
Knuth, Burning Books and Leveling Libraries: Extremist Violence and Cultural Destruction (Westport CT.: Greenwood Publishing, 2004).

${ }^{43}$ Biblio-quête also alludes to the real fire which partly destroyed the university library of Lyon in 1999, a unexplained conflagration reworked by Dider Daeninckx to form part of a plot centred on Holocaust denial in his Ethique en toc (2000). Benson's text serves as a sequel to Ethique. For a discussion see Margaret-Anne Hutton's French Crime Fiction 1945-2000: Investigating World War II (Ashgate, 2013), pp. $185-88$.

${ }^{44}$ Battles and Schnapp, The Library Beyond the Book, p. 124.

${ }^{45}$ See for instance: Sara Brenneis, 'Dictatorship Noir: Post-War Spanish History in Carlos Ruiz Záfon's La sombra del viento', Romance Studies 26.1 (2008), pp. 61-73; Judith Meddick, 'The Telling of Memory in La sombra del viento by Carlos Ruiz Záfon', Romance Studies, 28.4 (2010), pp. 246-58; Glennis and Gordon Byron, 'Barcelona gothic: Carlos Ruiz Zafón’s La sombra del viento and the omnipresent past', Journal of Romance Studies, 12.1 (2012), pp, 72-84.

${ }^{46}$ Robert Ellis, 'Reading the Spanish Past: Library Fantasies in Carlos Ruiz Zafón's La sombra del viento', Bulleting of Spanish Studies, 83.6 (2006), pp. 839-54 [846]. ${ }^{47}$ The motifs of the missing mother and physically abusive father appear most recently in David Whitehouse's The Mobile Library (Picador, 2015). ${ }^{48}$ Ali Smith, Public Library and other stories (Penguin Books, 2016), p. 19. ${ }^{49}$ The nostalgic libraries-as-spaces represented in the literary corpus belong to an era which not only predates both digitisation and the multimedia library space, but also the rise of 'young adult' fiction: in the days of these libraries young bibliophiles entered the children's section, waiting some years before access was granted to the adult lending rooms. 
